\title{
COMPARATIVE EFFICACY OF WHOLE AND DISINTE- GRATED KILLED VACCINES AGAINST SALMONELLA TYPHIMURIUM IN MICE
}

\author{
Sujatha Cronly-Dillon* \\ Department of Bacteriology, University of Edinburgh
}

STUDIES on immunisation against mouse typhoid have shown that killed vaccines confer protection against intraperitoneal challenge (Topley, Greenwood and Wilson, 1931; Raistrick and Topley, 1934; Hobson, 1957a), but this protection has usually resulted only in increase in survival time and not in significant reduction of mortality rate. However, MacLeod (1954) described a heat-killed vaccine which caused a significant reduction in mortality rate among mice challenged by the intraperitoneal but not by the oral route, which is presumably the natural route of infection. This result has recently been confirmed (CronlyDillon, 1967) in that heat-killed and acetone-killed vaccines which significantly reduced mortality among mice challenged by the intraperitoneal route did not protect against oral challenge. In the present investigation, an attempt has been made to produce a vaccine effective against challenge by either the oral or the intraperitoneal route by ultrasonic or Mickle disintegration of Salmonella typhimurium.

\section{MATERIALS AND METHODS}

Male Swiss white mice weighing 19-22 g were used. They were fed on a salmonella-free pellet diet and had free access to drinking water. Random samples of each stock of mice were tested by culture of the organs to exclude the possibility of natural infection with salmonellae.

Salmonella typhimurium strain 1566, phage type 1a/U57, derived from freeze-dried stock was used for the preparation of vaccines and for the challenge.

\section{Preparation of vaccines}

S. typhimurium was grown in nutrient broth for $6 \mathrm{hr}$ at $37^{\circ} \mathrm{C}$. A subculture was made on nutrient agar and, after overnight incubation at $37^{\circ} \mathrm{C}$, a smooth colony was selected. The identity of this colony was checked serologically and the organism grown overnight in nutrient broth at $37^{\circ} \mathrm{C}$. This culture was used to seed four Roux flasks of nutrient agar which were incubated overnight in the horizontal position at $37^{\circ} \mathrm{C}$. The resulting growth was harvested by transferring $20 \mathrm{ml}$ of sterile physiological saline into each Roux flask and rocking for a few minutes while the agar surface was gently scraped with a bent glass rod. The bacterial suspensions from all four flasks were pooled and centrifuged at low speed to deposit the cells which were then resuspended in $80 \mathrm{ml}$ of physiological saline. At each stage of the operation a sample was plated on to nutrient agar and the identity of the colonies confirmed serologically.

Heat-killed phenol-preserved vaccine (HK)

Half $(40 \mathrm{ml})$ of the bacterial suspension was heated at $56^{\circ} \mathrm{C}$ for $1 \mathrm{hr}$ in a waterbath and phenol added to a concentration of 0.5 per cent. as a preservative. Samples were cultured to

Received 19 Aug. 1971; accepted 20 Oct. 1971.

* Present address: Department of Bacteriology and Virology, University of Manchester.

J. MED. MICROBIOL.-VOL. 5 (1972) 
exclude the presence of viable bacteria. The vaccine was stored at $4^{\circ} \mathrm{C}$ until required. The vaccine was found by comparison with Brown's opacity tubes to contain approximately $1.7 \times 10^{10}$ organisms per ml. Just before use it was diluted in physiological saline to contain approximately $1.7 \times 10^{8}$ organisms per $\mathrm{ml}$.

\section{Acetone-killed freeze-dried vaccine (AK)}

The remaining $40 \mathrm{ml}$ of suspension were kept in broken ice or in the refrigerator at $4^{\circ} \mathrm{C}$ to prevent possible loss of heat-labile antigens. The bacteria were killed by adding three volumes of acetone at $4^{\circ} \mathrm{C}$ and the precipitate was washed six times with cold acetone. The precipitate was stored at $4^{\circ} \mathrm{C}$ for $72 \mathrm{hr}$ at which time culture confirmed that the organisms had been killed. The killed organisms were resuspended in cold acetone and 10-ml volumes transferred to freeze-drying ampoules and centrifuged at low speed. The supernatant was discarded and the vaccine freeze-dried and stored until required. Just before use, physiological saline was added until comparison with Brown's opacity tubes showed the vaccine to contain approximately $10^{8}$ organisms per $\mathrm{ml}$.

\section{Disintegrated vaccines}

Ultrasonic disintegration. Volumes $(2 \mathrm{ml})$ of $\mathrm{HK}$ and $\mathrm{AK}$ vaccines containing approximately $1.7 \times 10^{10}$ organisms per $\mathrm{ml}$ were washed three times in cold distilled water in a refrigerated centrifuge. The deposit was resuspended in $20 \mathrm{ml}$ amounts of cold distilled water and $3 \mathrm{ml}$ samples treated in an ultrasonic disintegrator (Measuring and Scientific Equipment, Ltd, London) for 20 min.

Mickle disintegration. Ten $\mathrm{ml}$ samples of vaccine were shaken with an equal volume of grade 12 Ballotini beads in a Mickle disintegrator for $20 \mathrm{~min}$. at a frequency of 50 cycles per $\mathrm{s}$. and an amplitude of about $5 \mathrm{~cm}$. The beads were then deposited from the suspension by centrifugation at low speed.

Examination under the electron microscope of shadowed preparations of vaccines disintegrated by either method confirmed that the organisms were fragmented, the ultrasonic method having the greater effect. Just before use, disintegrated vaccines were diluted with physiological saline to contain the equivalent of $1.7 \times 10^{8}$ organisms per ml calculated on the basis of their original bacterial content.

\section{Vaccine from infected mouse organ homogenates}

Four mice were each infected intraperitoneally with $c .4 \times 10^{4}$ organisms of $S$. typhimurium. The mice were killed 6 days later when they were moribund. Four normal mice were killed at the same time to provide control material. The large infecting dose was given so that organs containing high concentrations of salmonellae could be harvested before antibody was produced in significant amounts. Agglutinating antibodies to $S$. typhimurium were not detected in pooled samples of serum from heart blood of these mice. The spleen and liver were removed aseptically and kept in broken ice or at $4^{\circ} \mathrm{C}$ at all stages of the vaccine preparation. Four separate pools were made of the infected and normal spleen and liver; each was homogenised in a 4-ml volume of cold physiological saline for about $2 \mathrm{~min}$. in a Griffiths' tube and then disintegrated ultrasonically for $20 \mathrm{~min}$. Viable counts (Miles, Misra and Irwin, 1938) showed the preparations from normal mice to be sterile, and those from infected mice to contain about $2 \times 10^{5} \mathrm{~S}$. typhimurium per ml. The homogenates were centrifuged at $2000 \mathrm{~g}$ for $1 \mathrm{hr}$ at $4^{\circ} \mathrm{C}$ and the supernate was removed by filtration through an Oxoid membrane. Portions of filtrate plated on nutrient agar and incubated overnight at $37^{\circ} \mathrm{C}$ were sterile.

\section{Administration of vaccines}

Tests of potency

The vaccines administered as a single subcutaneous injection $(0.1 \mathrm{ml}$ for $\mathrm{HK}$ or AK vaccine and $0.5 \mathrm{ml}$ for organ homogenate extract) at the root of the tail were shown to be non-toxic and non-infective to mice. 


\section{Challenge procedure}

The challenge organism was taken from the lyophilised state and grown overnight in nutrient broth at $37^{\circ} \mathrm{C}$. The suspension was centrifuged at a low speed $(c .1500 \mathrm{~g})$ and the deposit resuspended in $0.1 \mathrm{M}$ phosphate buffer at $p \mathrm{H} 8$ to an approximate concentration of $10^{8}$ organisms per ml, as judged by Brown's opacity tubes. Serial ten-fold dilutions were made in phosphate buffer to give the appropriate concentrations for challenge. The challenge was given in a $0.1 \mathrm{ml}$ volume, and the actual dose administered was determined in each case from a viable count on the suspension (Miles et al., 1938).

Animals were challenged orally by injecting $0.1 \mathrm{ml}$ of suspension through a narrow polythene cannula $(0.5 \mathrm{~mm}$ bore) passed into the stomach.

\section{Care of mice after infection}

After infection, mice were housed in threes in cages which were cleaned frequently; they were transferred once during the course of each experiment to freshly sterilised cages in an attempt to reduce the chances of cross- and auto-reinfection. The mice were examined twice daily and immediate necropsy was performed on dead animals. On the 28th day after challenge, all animals were killed and examined post mortem for bacteriological evidence of infection. The infection rate, the mortality rate and mean time to death of the fatal cases were then calculated for each group.

\section{Relative potency of disintegrated and whole $H K$ and $A K$ vaccines}

Groups of 20 mice were immunised with the equivalent of $10^{7}$ organisms, given as ultrasonically or Mickle disintegrated preparations or as whole $\mathrm{HK}$ and AK vaccines, and challenged intraperitoneally with $4 \times 10^{1} S$. typhimurium on the 15 th day after immunisation. Groups of 16 similarly immunised mice were challenged on the 15th day with $4 \times 10^{7} S$. typhimurium given by the oral route. Equal numbers of non-immunised mice were challenged in the same way.

\section{Infected mouse organ homogenates as vaccines}

Groups of five mice were given a single subcutaneous injection of $0.5 \mathrm{ml}$ of the sterile filtered extract from infected tissue homogenates. Control groups of five mice received similar injections of homogenates from normal mice or normal saline. On the 15th day after vaccination, all of the mice were challenged with a dose of $3 \times 10^{4} S$. typhimurium given by the intraperitoneal route.

\section{Statistical analysis}

The results were analysed by the $\chi^{2}$ test of probability using the formula that makes allowance for small numbers:

$$
\chi^{2}=\frac{\left\{a d-b c-\frac{1}{2}(a+b+c+d)\right\}^{2}(a+b+c+d)}{(a+b)(c+d)(a+c)(b+d)} .
$$

When the value for $\mathbf{P}$ was $\mathbf{0 . 0 5}$ or less, the result was considered to be significant.

\section{RESULTS}

\section{Protective potencies of disintegrated or whole $H K$ and $A K$ vaccines}

Protection against oral challenge. With an oral challenge of $4 \times 10^{7}$ organisms per mouse, unimmunised controls showed a mortality rate of 58 per cent. (mean time to death 19 days) and an infection rate of 100 per cent. (table I). Among the vaccinated animals, only the group that received $10^{7}$ Mickle-disintegrated 
HK vaccine organisms showed a statistically significant reduction in mortality. Rates of infection were not reduced and mean survival times of the fatal cases were not prolonged in any group.

Protection against intraperitoneal challenge. With an intraperitoneal challenge dose of $4 \times 10^{1}$ Salmonella typhimurium per mouse, animals that had been immunised with $10^{7}$ whole HK or AK vaccine organisms or with the Mickle or ultrasonically disintegrated forms all showed a statistically significant reduction in mortality rates (table II). Infection rates were also significantly reduced in

TABLE I

Protective potencies of $H K$ and $A K$ vaccine after ultrasonic or Mickle disintegration in groups of 16 mice assessed over 28 days after oral challenge with $4 \times 10^{7}$ Salmonella typhimurium

\begin{tabular}{l|l|c|c|c}
\hline \multicolumn{2}{c|}{$\begin{array}{l}\text { Vaccine* and method } \\
\text { of disintegration }\end{array}$} & $\begin{array}{c}\text { Mortality } \\
\text { rate } \\
\text { (per cent.) }\end{array}$ & $\begin{array}{c}\text { Infection } \\
\text { rate } \\
\text { (per cent.) }\end{array}$ & $\begin{array}{c}\text { Mean survival time } \\
\text { of mice that died } \\
\text { (days) }\end{array}$ \\
\hline Heat-killed & Ultrasonic & 25 & 100 & 13 \\
& Mickle & $13 \dagger$ & 88 & 19 \\
& Untreated & 38 & 100 & 16 \\
\hline \multicolumn{2}{|c|}{ None } & 58 & 100 & 19 \\
\hline \multirow{2}{*}{ Acetone-killed } & Ultrasonic & 60 & 100 & 13 \\
& Mickle & 38 & 88 & 16 \\
& Untreated & 38 & 94 & 13 \\
\hline
\end{tabular}

* Dose $10^{7}$ organisms or equivalent.

$\dagger$ Indicates that the result differed significantly from that in unimmunised controls ( $\chi^{2}$ test of probability).

mice immunised with whole and ultrasonically disintegrated $\mathrm{AK}$ vaccine but not Mickle-disintegrated AK vaccine. Mean survival times were increased in all groups.

\section{Immunisation with infected organ homogenates}

The results of this series of experiments are given in table III. Intraperitoneal challenge with $3 \times 10^{4} S$. typhimurium produced 100 per cent. mortality and 100 per cent. infectivity in unimmunised control mice. Animals immunised with a single subcutaneous injection of sterile infected liver extract showed a statistically significant reduction in mortality rate $(P<0.05)$. The mortality in animals immunised with normal liver homogenate was less than that in animals given saline but the difference was not significant. Immunisation with extracts of spleen from normal and infected mice did not reduce mortality rates to an appreciable extent. No tissue extract had any effect on infection rates or on mean times to death for those mice that died. 
TABLE UI

Protective potencies of $H K$ and AK vaccine after ultrasonic or Mickle disintegration in groups of 20 mice assessed over 28 days after intraperitoneal challenge with $4 \times 10^{1}$ Salmonella typhimurium

\begin{tabular}{l|l|c|c|c}
\hline \multicolumn{1}{c|}{$\begin{array}{c}\text { Vaccine* and method } \\
\text { of disintegration }\end{array}$} & $\begin{array}{c}\text { Mortality } \\
\text { rate } \\
\text { (per cent.) }\end{array}$ & $\begin{array}{c}\text { Infection } \\
\text { rate } \\
\text { (per cent.) }\end{array}$ & $\begin{array}{c}\text { Mean survival time } \\
\text { of mice that died } \\
\text { (days) }\end{array}$ \\
\hline \multirow{2}{*}{ Heat-killed } & Ultrasonic & $0 \dagger$ & $20 \dagger$ & $\ldots$ \\
& Mickle & $0 \dagger$ & $50 \dagger$ & $\ldots$ \\
& Untreated & $0 \dagger$ & $15 \dagger$ & $\ldots$ \\
\hline \multirow{4}{*}{ None } & 75 & 95 & 10 \\
\hline \multirow{2}{*}{ Acetone-killed } & Ultrasonic & $0 \dagger$ & $55 \dagger$ & $\ldots$ \\
& Mickle & $15 \dagger$ & $70 \dagger$ & 20 \\
& Untreated & $5 \dagger$ & $40 \dagger$ & 14 \\
\hline
\end{tabular}

* Dose $10^{7}$ organisms or equivalent.

$\dagger$ Indicates that the result differed significantly from that in unimmunised controls ( $\chi^{2}$ test of probability).

TABLE III

Protective effect of bacteria-free extracts of organs of infected mice in groups of five mice challenged intraperitoneally 14 days after vaccination with $3 \times 10^{4} S$. typhimurium. The experiment was terminated 28 days after challenge

\begin{tabular}{l|c|c|c}
\hline $\begin{array}{c}\text { Tissue from which sterile } \\
\text { vaccine was prepared }\end{array}$ & $\begin{array}{c}\text { Number of mice } \\
\text { that died }\end{array}$ & $\begin{array}{c}\text { Number of mice } \\
\text { infected with } \\
\text { S. typhimurium }\end{array}$ & $\begin{array}{c}\text { Mean survival time of } \\
\text { mice that died (days) }\end{array}$ \\
\hline $\begin{array}{l}\text { Infected spleen : } \\
\text { Normal spleen }:\end{array}$ & 4 & 5 & 11 \\
Infected liver $:$ & 4 & 5 & 13 \\
Normal liver : & $:$ & 5 & $\cdots$ \\
Control & $0^{*}$ & 5 & 10 \\
\hline
\end{tabular}

* Indicates that the result differed significantly from that in unimmunised controls $\left(\chi^{2}\right.$ test of probability).

\section{DISCUSSION}

The present work supports MacLeod's (1954) conclusion that vaccination of mice with whole heat-killed or acetone-killed vaccines significantly protects them against Salmonella typhimurium, when challenged intraperitoneally but not when challenged orally. The important observation here is that when Mickledisintegrated $\mathrm{HK}$ vaccine was administered to mice it protected them against a challenge inoculum of $S$. typhimurium given either by the oral route or 
intraperitoneally. The present results indicate that heat-killed organisms can be made into a potent vaccine against oral challenge by Mickle disintegration. Of the vaccines studied, this was the only form that brought about a significant reduction in mortality in mice challenged by the natural oral route of infection. Infection rates and survival rates were not significantly affected. It appears that the physical form of a vaccine is important in relation to its potency against a challenge delivered by a specific route. It is possible that the Mickle disintegration process applied to whole HK vaccine served to reveal more or different antigenic sites. Particulate antigens are known to be superior to soluble antigens in their ability to stimulate antibody production (Weir, 1967). Mickle disintegration yielded particles of a larger size than the ultrasonic disintegration and it is possible that ultrasonic disintegration made soluble a proportion of the cellular material, leaving insufficient particulate material to stimulate protective mechanisms against an oral challenge.

Good protection was conferred against intraperitoneal challenge by all $\mathrm{HK}$ and $\mathrm{AK}$ intact and disintegrated vaccines in terms of reduced mortality and infection rates as well as prolonged survival times.

It has often been noted that recovery from mouse typhoid offers the best protection against subsequent challenge (Hobson, 1957 $a$ and $b$ ). More recently, Kawakami, Osawa and Mitsuhashi (1966) suggested that an immunity-producing substance is absent from artificially cultured $S$. enteritidis but develops during infection as a result of host-parasite interaction. Immunisation with a bacteriafree extract of homogenised liver from infected mice significantly reduced mortality in mice challenged intraperitoneally with a large dose $\left(3 \times 10^{4}\right)$ of $S$. typhimurium. Active immunisation appeared to be playing a part since agglutinins were not demonstrated in the mice donating the antigen and an extract similarly prepared from infected spleen tissue did not confer protection. It appears that the liver is able to concentrate breakdown products of bacteria in a form suitable for use as an immunising antigen. Olitzki and Godinger (1963) reported that the livers of mice and guinea-pigs infected with $S$. typhi were rich in antigenic material and that $S$. typhi was a better immunogen when grown in vivo than in vitro.

\section{SUMMARY}

Groups of mice were immunised against Salmonella typhimurium with heatkilled $(\mathrm{HK})$ and acetone-killed (AK) vaccines or with their ultrasonic or Mickledisintegrated forms and subsequently challenged by the oral or intraperitoneal routes. All six vaccine preparations conferred statistically significant protection against intraperitoneal challenge as measured by reduced mortality, lowered infection rate and prolonged survival. Of the six vaccines, only the Mickledisintegrated $\mathrm{HK}$ vaccine significantly reduced the mortality rate of mice challenged by the oral route.

Filtered bacteria-free extracts of homogenates of infected mouse liver conferred active immunity against a massive intraperitoneal challenge, but similar extracts of normal liver or of spleen from normal or infected animals were without effect. 
The author warmly acknowledges the advice and guidance of Professor R. Cruickshank and Dr J. G. Collee during the course of this work, and thanks the University of Edinburgh for generously providing a graduate research scholarship.

\section{REFERENCES}

Cronly-Dillon, Sujatha (née Panikker) 1967. M.Sc. Thesis, University of Edinburgh. Studies on infection and immunity in experimental mouse typhoid.

Hobson, D. 1957a. Resistance to reinfection in experimental mouse typhoid. J. Hyg., Camb., 55, 334.

Hobson, D. 1957b. Chronic bacterial carriage in survivors of experimental mouse typhoid. J. Path. Bact., 73, 399.

KawaKami, M., Osawa, N., and Mitsuhashi, S. 1966. Experimental salmonellosis. VII. Comparison of the immunizing effect of live vaccine and materials extracted from Salmonella typhimurium. J. Bact., 92, 1585.

MACLEOD, D. R. E. 1954. Immunity to salmonella infection in mice. J. Hyg., Camb., 52, 9.

Miles, A. A., MisRa, S. S., AND IRwIN, J. O. 1938. The estimation of the bactericidal power of the blood. J. Hyg., Camb., 38, 732.

OlitzKI, A. L., AND GodINGER, D. 1963. Comparative studies on Salmonella typhi grown in vivo and in vitro. III. The immunizing potencies of acetone-killed vaccines prepared from in vivo- and in vitro-grown bacteria and the immunizing potency of substances isolated from infected organs. J. Hyg., Camb., 61, 353.

RaIstrick, H., AND Topley, W. W. C. 1934. Immunizing fractions isolated from Bact. aertrycke. Br. J. Exp. Path., 15, 113.

Topley, W. W. C., Greenwood, M., AND Wilson, JoyCe 1931. A strain of Bact. aertrycke with unusual epidemic characters. J. Path. Bact., 34, 523.

WeIR, D. M. 1967. The immunological consequences of cell death. Lancet, 2, 1071. 